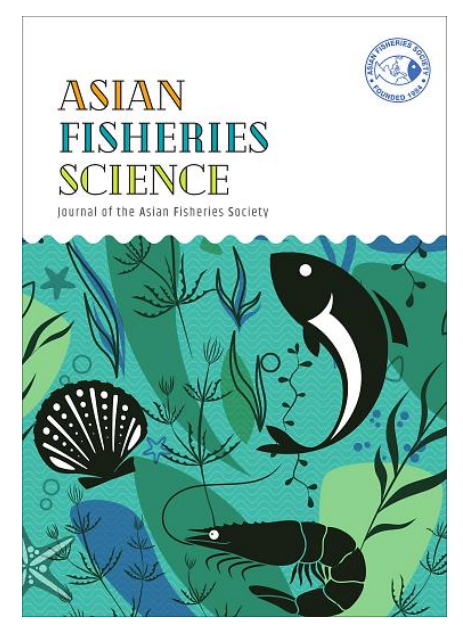

(ㄷ) Asian Fisheries Society

ISSN: 0116-6514

E-ISSN: 2073-3720

https://doi.org/10.33997/j.afs.2021.34.1.011

\section{COVID-19 and Small-Scale Fisheries in Southeast Asia: Impacts and Responses}

\author{
ALICE JOAN G. FERRER ${ }^{1, *}$, ROBERT POMEROY ${ }^{2}$, MICHAEL J. AKESTER ${ }^{3}$, \\ UMI MUAWANAH ${ }^{4}$, WATCHARAPONG CHUMCHUEN ${ }^{5}$, WEN CHIAT LEE ${ }^{6}$, \\ PHUNG GIANG HAI ${ }^{7}$, K. KUPERAN VISWANATHAN ${ }^{8}$ \\ 'University of the Philippines Visayas, Miagao, lloilo 5023, Philippines \\ 'University of Connecticut, 1080 Shennecossett Road, Groton, Connecticut 06340, United States of America \\ ${ }^{3}$ WorldFish, Yangon, Myanmar \\ ${ }^{4}$ Republik Indonesia Kementerian Kelautan dan Perikanan - BRSDMKP, Gedung Balitbang I, $4^{\text {th }}$ Floor, \\ Jin Pasir Putih I, Ancol Jakarta Utara, Jakarta 10100, Indonesia \\ ${ }^{5}$ Marine Fisheries Research and Development Division, Department of Fisheries, 50 Phahol Yothin Rd., Lad Yao, \\ Chatuchak, Bangkok 10900, Thailand \\ ${ }^{6}$ Universiti Teknologi MARA, Sarawak, Malaysia \\ ${ }^{7}$ Rural Institution Research, Institute of Policy and Strategy for Agriculture and Rural Development, \\ No.16 Thuy Khue Street, Hanoi 100000, Viet Nam \\ ${ }^{8}$ Othman Yeop Abdullah Graduate School of Business, Universiti Utara Malaysia, Sintok, Kedah, Malaysia
}

*E-mail: agferrer@upv.edu.ph |Received: 28/02/2021; Accepted: 23/04/2021

\begin{abstract}
This paper describes the impacts of and responses to COVID-19 of small-scale fisheries in six selected countries in Southeast Asia, including Indonesia, Malaysia, Myanmar, Philippines, Thailand, and Vietnam. The paper used a structured case study approach to analyse the impacts and responses and relied heavily on existing reports and data sources in each country. The pandemic has further revealed the vulnerability of small-scale fishing households in the region. Given the few assets of fisher households, their ability to cushion the negative impact of crises and shocks is limited. Fishers made adaptive responses such as direct fish marketing, online marketing, and home delivery services. While short-term responses of providing food and financial assistance have been helpful, long-term support to address pandemics such as COVID-19 and other stressors will require developing more resilient fishing households. The paper recommends several approaches and interventions to improve household resilience and to be better prepared for similar challenges and threats in the future. These include: i) strengthening the fishing households' social network of friends, relatives, and neighbours to serve as both a social safety net and a bridge towards the transition to financial inclusion; ii) diversifying livelihood to reduce dependency on the fishery and provide for additional sources of income and food; iii) promoting financial inclusion through savings, credit, digital payment products, and insurance; iv) value chain upgrading through post-harvest fish handling and processing methods; and, v) providing access, especially for women, to social protection measures such as government health insurance and social security.
\end{abstract}

Keywords: pandemic, vulnerability, coastal livelihood, coping, fishers

\section{Introduction}

Southeast Asian countries were hit hard by COVID-19. The health and economic impact of COVID-19 has been significant across the region, but the virus has not spread as quickly as in other parts of the world (CSIS, 2020; United Nations, 2020). This is partly due to the draconian measures taken by countries in the region, such as cross-border travel restrictions and lockdowns (Marschke et al., 2020). However, actions to control the spread of COVID-19 in the region have been uneven (Fig. 1). The pandemic has brought about real suffering for people, especially vulnerable groups, in the region and highlighted prevailing inequities, risks and challenges ranging from lack of social protection to human rights, damaged ecosystems and biodiversity loss (Love et al., 2020).

The rapid spread of COVID-19 throughout Southeast Asia (SEA) has affected the region's small-scale fishers and fish value chain actors in capture and culture fisheries (CSIS, 2020; Clavelle, 2020; FAO, 2020a; FAO, 2020b; Knight et al., 2020; Love et al., 2020; Bennett et al., 2020). Fisher and fisher household's livelihoods, nutrition, and health have been affected. Fishers have met difficulties due to the national lockdown 


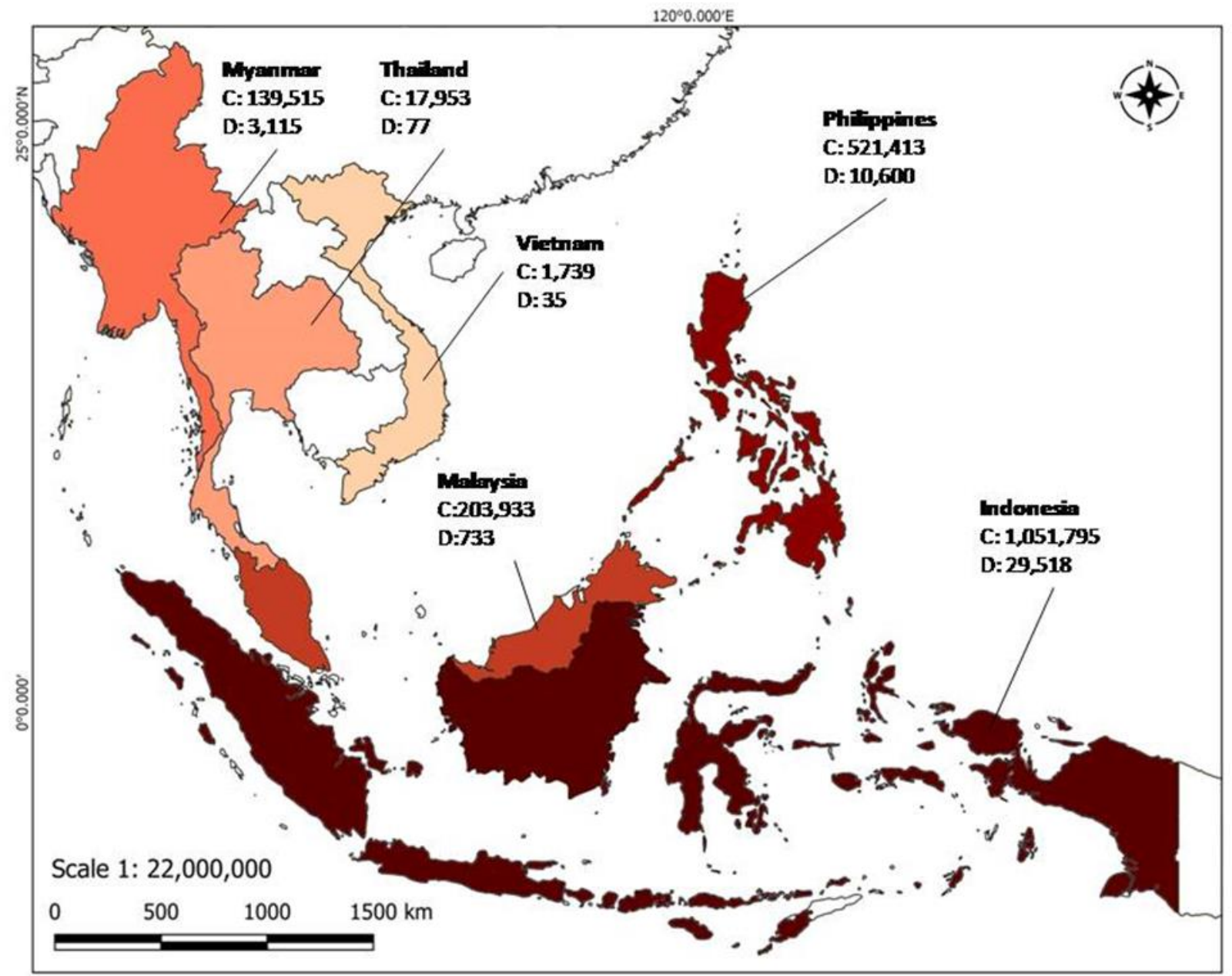

Fig. 1. Total number of confirmed COVID-19 cases (C) and deaths (D) as of 30 January 2021 in Indonesia, Malaysia, Myanmar, the Philippines, Thailand, and Vietnam. (Source: https://covid19.who.int).

measures in many countries that prohibit them from going out to sea to fish or from selling their fish. Due to reduced demand for seafood from local markets, restaurants, and hotels, the collapse of prices has reduced fishing activity. Input suppliers, traders, processors, transporters, financiers, and others in the small-scale fisheries value chain have seen a decrease in activities. Access to ice, fuel, bait, and fishing gear has been restricted due to suppliers closing due to limited fishing activity. Trade has slowed as transportation restrictions prevent the movement of products. Seafood processing facilities are closed or operating at reduced capacity.

The existing challenges and vulnerabilities faced by the small-scale fisheries sector in SEA - poverty; market access; financial services; livelihoods; poor access to public services such as health care, clean water, and sanitation; social protection; political and economic marginalisation; gender inequity; natural disasters - have been exacerbated due to COVID-19 (Knight et al., 2020; Marschke et al., 2020). Small-scale fishers have been especially vulnerable since many depend upon daily catch to feed and support their families. Many fishers have become deeper in debt as they borrow from informal financial sources to support themselves and their families (Drury O'Neill et al., 2019; Marschke et al., 2020). Women are especially vulnerable, facing a higher risk of infection as they most often work in the post-harvest sector where they have greater direct interaction with potentially infected fish sellers and buyers (Drury O'Neill et al., 2019).

It is not all bad news, as small-scale fishers, households, and communities in the region are adapting to the pandemic and showing resilience (FAO, 2020a; Belton et al., 2021). Fishing practices are changing, new markets and alternative marketing strategies are being developed, and improved postharvest handling, hygiene, and sanitation practices are being employed. Safety-at-sea and safety in the market practices are being implemented. Governments, non-governmental organisations, the private sector, and donors are taking a variety of actions to support the small-scale fisheries sector, including providing economic relief and public services, development of markets, developing or strengthening social protection measures, financial inclusion, and capacity building (Love et al., 2020).

The purpose of this paper is to report on the impacts 
of and responses to COVID-19 of small-scale fishers, households, and communities in six selected countries in Southeast Asia (Indonesia, Malaysia, Myanmar, Philippines, Thailand, and Vietnam). The paper uses a structured case study approach to the analysis of the impacts and responses. The paper provides a national and regional perspective on the emerging lessons learned to date. The pandemic has further revealed the vulnerability of small-scale fishing households in the region. The paper recommends several approaches and interventions to improve household resilience and be better ready for future challenges and threats.

\section{Materials and Methods}

The COVID-19 pandemic and associated lockdowns in the SEA countries have forced the use of existing data sources rather than collection of primary data. The paper used a structured case study approach to analyse the impacts of COVID-19 and the responses of the fishers. This desk study relied heavily on existing reports and data sources in each country. These include official government data available, other studies collected, posts of relevant government agencies on official social media accounts, and news carried by major national dailies. No primary data collection was undertaken. A uniform outline was used in each case country. The topics included in the outline were: i) the disruption of small-scale fisheries (i.e., ability to fish, fish processing, selling); ii) coping strategies (i.e., selling, markets, value-added, alternative livelihoods); iii) relief and support received (i.e., government food and cash, low interest loans, fish marketing); and iv) emerging lessons. The small- scale fisheries in each country were described in terms of types of fishing boats, engines, and gears used, and the location of their operation. The roles of women in fisheries played before and during the pandemic were identified and described.

\section{Country Case Studies}

The case studies of the six countries are presented in this section. A summary of characteristics of smallscale fisheries in the six countries selected for case studies is shown in Table 1. These included information on the boats and engines they use (not using boats or using boats of $<10 \mathrm{GT}$; using engines of 25 to 50HP), gears (hook and line, bag net, trammel net, lift net, driftnets, gillnets, longlines, traps, and other passive gears), and location of fishing activities (inland, inshore, nearshore; within $15 \mathrm{~km}$ from the shoreline). A summary of the case studies is presented in Table 2.

\section{Indonesia}

\section{Disruption to small-scale fisheries}

Indonesia was under total lockdown from March to May 2020 in response to the COVID-19 pandemic. The lockdown affected the domestic transportation of seafood products, impacting seafood supply throughout the value chain. Estimates show a $70 \%$ decline in fish supply for hotels, restaurants, and cafés, and a $40 \%$ reduction in household fish consumption.

Table 1. Summary characteristics of small-scale fisheries in six Southeast Asian countries.

\begin{tabular}{|c|c|c|c|c|c|c|}
\hline & Indonesia & Malaysia & Myanmar & Philippines & Thailand & Vietnam \\
\hline $\begin{array}{l}\text { Boat } \\
\text { lengine }\end{array}$ & $\begin{array}{l}<10 \mathrm{GT}^{\mathrm{a}} \\
<4 \mathrm{HP}^{\mathrm{b}}\end{array}$ & $\begin{array}{l}\text { Not using boat or } \\
\text { use boat of } 24 \mathrm{ft} \\
\text { and smaller, and } \\
\text { with engine power } \\
\text { (if any) of } 25 \mathrm{HPc,d}\end{array}$ & $\begin{array}{l}\text { Use vessels less } \\
\text { than } 30 \mathrm{ft} \text { long } \\
\text { and with engine } \\
\text { power (if any) of } \\
\text { less than } 25 \mathrm{HP}\end{array}$ & $\begin{array}{l}\text { With no boats or } \\
\text { use boats } 3 G T \text { and } \\
\text { below }\end{array}$ & $<10 \mathrm{GT}$ & $\begin{array}{l}\text { Small } \\
\text { fishing } \\
\text { boats and } \\
\text { small } \\
\text { engines, } \\
45-50 \mathrm{HP}\end{array}$ \\
\hline Gear & $\begin{array}{l}\text { Seine nets, gill } \\
\text { nets, traps and } \\
\text { other } \\
\text { traditional } \\
\text { gears such as } \\
\text { shellfish } \\
\text { collections, } \\
\text { seaweed } \\
\text { collections and } \\
\text { cast net }\end{array}$ & $\begin{array}{l}\text { Handlines, } \\
\text { longline, hook and } \\
\text { line, bag net, } \\
\text { trammel net, lift } \\
\text { net, traps, and } \\
\text { other Use } \\
\text { traditional, } \\
\text { sustainable } \\
\text { fishing gears }\end{array}$ & $\begin{array}{l}\text { Driftnets, gillnets, } \\
\text { and longlines. }\end{array}$ & $\begin{array}{l}\text { Hook and lines, } \\
\text { traps, fish coral, } \\
\text { lift nets, gillnets, } \\
\text { scoop nets, cast } \\
\text { nets, seine nets, } \\
\text { and other passive } \\
\text { gears }\end{array}$ & $\begin{array}{l}\text { Hook and lines, } \\
\text { gillnets, falling } \\
\text { nets, and traps }\end{array}$ & $\begin{array}{l}\text { Scoop } \\
\text { nets, cast } \\
\text { nets, } \\
\text { seine } \\
\text { nets, lift } \\
\text { net, hook } \\
\text { and line, } \\
\text { traps }\end{array}$ \\
\hline $\begin{array}{l}\text { Fishing } \\
\text { zone }\end{array}$ & $\begin{array}{l}\text { Nearshore, } \\
\text { inland }\end{array}$ & $\begin{array}{l}\text { Operate not more } \\
\text { than } 5 \text { nautical } \\
\text { miles from shore }\end{array}$ & $\begin{array}{l}\text { Inshore and area } \\
\text { within } 10 \text { nautical } \\
\text { miles from the } \\
\text { shoreline }\end{array}$ & $\begin{array}{l}\text { Inland and waters } \\
\text { within } 15 \mathrm{~km} \text { away } \\
\text { from the } \\
\text { shoreline }\end{array}$ & $\begin{array}{l}\text { Inshoreg; operate } \\
\text { within } 12 \text { nautical } \\
\text { miles from } \\
\text { shoreline }^{\text {h }}\end{array}$ & $\begin{array}{l}\text { Near and } \\
\text { inshore }^{e, f}\end{array}$ \\
\hline
\end{tabular}

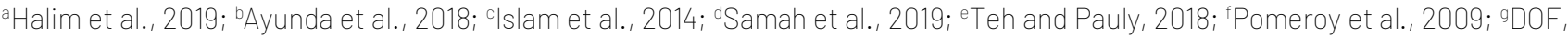
2015; ' $M D, 2018$. 
Table 2. Summary matrix of the impacts of COVID-19 in six Southeast Asian countries.

\begin{tabular}{|c|c|c|c|c|c|c|}
\hline Indicators & Indonesia & Malaysia & Myanmar & Philippines & Thailand & Vietnam \\
\hline \multicolumn{7}{|c|}{ Main policy response to COVID-19 } \\
\hline $\begin{array}{l}\text { National } \\
\text { lockdown }\end{array}$ & $\begin{array}{l}\text { Yes, gradual, } \\
\text { decentraliseda }\end{array}$ & $Y_{e s}^{b}$ & Yes $^{\mathrm{C}}$ & $\begin{array}{l}\text { Yes, gradual, } \\
\text { decentralised }^{d}\end{array}$ & Yes & $\begin{array}{l}\text { Yes, in selected } \\
\text { areas }\end{array}$ \\
\hline $\begin{array}{l}\text { Health } \\
\text { protocols }\end{array}$ & Yes & Yes & Yes & Yes & Yes & Yes \\
\hline \multicolumn{7}{|l|}{ Disruptions } \\
\hline $\begin{array}{l}\text { Less fishing } \\
\text { activities }\end{array}$ & Yes & $\begin{array}{l}\text { Yes } \\
\text { with curfewe }\end{array}$ & Yes $^{\dagger}$ & Yes & $\begin{array}{l}\text { Yes, } \\
\text { with curfew }\end{array}$ & Yes $^{g}$ \\
\hline Low demand & Yes & Yes & Yes & Yes & Yes & Yes \\
\hline Low prices & Yes & Yes & Yes & Yes & Yes & Yes \\
\hline $\begin{array}{l}\text { Difficult } \\
\text { marketing }\end{array}$ & Yes & Yes & Yes & Yes & Yes & Yes \\
\hline Income loss & Yes & Yes & Yes & Yes & Yes & Yes \\
\hline \multicolumn{7}{|c|}{ Coping strategies } \\
\hline $\begin{array}{l}\text { Continued } \\
\text { fishing } \\
\text { Direct selling } \\
\text { of fish } \\
\text { Others }\end{array}$ & $\begin{array}{l}\text { Yes, mostly } \\
\text { for food } \\
\text { Yes, community } \\
\text { and online } \\
\text { Women fish } \\
\text { traders sold other } \\
\text { agri-products and } \\
\text { intensified fish } \\
\text { processing }\end{array}$ & $\begin{array}{l}\text { Yes, mostly } \\
\text { for food } \\
\text { Yes, community } \\
\text { Continued to } \\
\text { receive } \\
\text { government's } \\
\text { monthly cash and } \\
\text { fuel subsidy }\end{array}$ & $\begin{array}{l}\text { Yes, mostly for } \\
\text { food } \\
\text { Yes, } \\
\text { Community }\end{array}$ & $\begin{array}{l}\text { Yes, mostly for } \\
\text { food } \\
\text { Yes, community } \\
\text { and online }\end{array}$ & $\begin{array}{l}\text { Yes } \\
\text { Yes, community } \\
\text { and online; } \\
\text { Fishers } \\
\text { intensified } \\
\text { processing }\end{array}$ & $\begin{array}{l}\text { Yes } \\
\text { Yes, community }\end{array}$ \\
\hline \multicolumn{7}{|c|}{ Relief and support received } \\
\hline $\begin{array}{l}\text { Cash and in- } \\
\text { kind (food) } \\
\text { relief } \\
\text { assistance }\end{array}$ & $\begin{array}{l}\text { Yes; from the } \\
\text { government and } \\
\text { private sector }\end{array}$ & $\begin{array}{l}\text { Yes, one time } \\
\text { government cash } \\
\text { support }\end{array}$ & None & $\begin{array}{l}\text { Yes; } \\
\text { government and } \\
\text { private sector }^{\text {h }}\end{array}$ & $\begin{array}{l}\text { Yes, also daily } \\
\text { subsistence } \\
\text { goods; from } \\
\text { government and } \\
\text { private sector }\end{array}$ & $\begin{array}{l}\text { Yes, from the } \\
\text { government }\end{array}$ \\
\hline $\begin{array}{l}\text { Low interest } \\
\text { loan }\end{array}$ & None & None & $\begin{array}{l}\text { Yes, from the } \\
\text { government }\end{array}$ & $\begin{array}{l}\text { Yes, zero interest } \\
\text { loan from the } \\
\text { government }\end{array}$ & $\begin{array}{l}\text { Yes, from the } \\
\text { government and } \\
\text { private sector }\end{array}$ & $\begin{array}{l}\text { Yes, from the } \\
\text { government }\end{array}$ \\
\hline $\begin{array}{l}\text { Provision of } \\
\text { livelihood } \\
\text { support }\end{array}$ & $\begin{array}{l}\text { Yes, from the } \\
\text { governmentj }\end{array}$ & $\begin{array}{l}\text { Yes, from the } \\
\text { government and } \\
\text { the private } \\
\text { sectork }\end{array}$ & & $\begin{array}{l}\text { Yes, from the } \\
\text { government }\end{array}$ & & \\
\hline
\end{tabular}

Others

\author{
Fundraising \\ activities by \\ the private sector
}

\begin{abstract}
Notes: Lockdown: ${ }^{a}$ decentralised and gradual way starting March, national State of Emergency starting April 2020; ${ }^{b}$ known as Movement Control Order (MCO), enhanced MCO from March to May, with national travel ban and lockdown in five states, conditional MCO starting May; ${ }^{c}$ First lockdown on April 18 (related to the $1^{\text {st }}$ wave), eased May to July - assumed the problem was over; instated August to September (related to the $2^{\text {nd }}$ wave); ${ }^{d}$ known as community quarantine under different strictness levels --Enhanced/General- modified, with the national government classifies local governments under levels of community quarantine; Reduction in fishing: eUnemployed labor returning to villages from Myanmar and abroad has resulted in increased fishing pressure by those without incomes seeking access to food. ${ }^{f}$ others voluntarily stopped fishing; ${ }^{9}$ voluntary reduction in fishing efforts for some fishers; Cash and in-kind relief: hthe national government provided one time cash and food assistance, while the local governments provided food assistance; ithe national government provided financial assistance (around USD160 per person from April to June 2020, while the local governments also provided food and daily subsistence goods. Provision of livelihood support: Jgovernment support for campaigns to increase fish demand and online marketing, opening of cold storage for public use, fish in relief packages; ${ }^{k}$ improvement in food storage and distribution infrastructure, alternative livelihood assistance, fisheries association and the government bought their catch; 'provision of production inputs in fishing and fish cage farming, fish in relief packages from the local government.
\end{abstract}


Fishing in Indonesia is dominated by small-scale fishers (SSF). The SSF, along with small fish farmers, small fish processors, and traders, were heavily affected by the COVID-19 pandemic (Rare Indonesia, 2020). During the lockdown, transportation uncertainty and irregularity, the lower purchasing power of the consumers, and the closure of businesses (restaurant, catering, and hotels) forced local traders to sell fish in local markets at much lower prices than before COVID-19 (Mardhia et al., 2020). For tuna fisheries in the Moluccas, the price decline ranged between $25 \%$ and $37 \%$, while the hand-liners suffered a price decline that ranged between $17 \%$ and $21 \%$ (MDPI, 2020). Similarly, in Cirebon, West Java, the low seafood prices led to low income for fishers who were facing high operation cost. By June 2020, fishers were not fishing anymore since the operational cost was higher than the revenue.

The decline in fish prices and rise in transportation costs led to lower fish supply and impacts on the economic welfare of fishers. The total fishing income of small gillnet fishers in Bengkulu, in the southern part of Sumatera Island, were estimated to be IDR78,985,000.00 (USD5596.08) from March to December 2020 (during COVID-19), which was much lower than their fishing income of IDR189,937,142.86 (USD13451.64) earned from October 2019 to February 2020 (before COVID-19) (Kholis et al., 2020). In South Sulawesi, half of the 185 fishers who participated in a survey identified the low demand for fish from traders and the decline in the price of fish as primary reasons for the decrease in their income (Campbell et al., 2020). A survey by Rare Indonesia (2020) showed that $70 \%$ of the traders in South-East Sulawesi $(n=37)$ felt that COVID-19 was negatively impacting their fisheries business.

\section{Coping strategies}

The survey by Rare Indonesia (2020) in South Sulawesi showed that the fishers continued fishing throughout 2020. Similarly, Campbell et al. (2020) found that 80 $\%$ of men and women fishers continued to fish, and 65 $\%$ to $76 \%$ of men and women traders continued to sell fish during the pandemic. Despite the lower-income earned than before COVID-19, fishers and traders viewed their continued activities as their contribution to food security (Rare Indonesia, 2020). Moreover, the processing sector turned to online selling of their products.

At the household level, the role of women is crucial in securing household resilience during the pandemic. Wives helped to sell the fish through retail marketing to households in nearby communities. Often, wives created an alternative livelihood during the pandemic, such as selling food and drinks and taking part-time jobs such as becoming a housemaid (Field Observation, Cirebon, July 2020).

\section{Relief and support}

The support to SSF came from various sources in the form of financial and non-financial types of interventions and initiatives that were taken during the early stage of COVID-19 lockdown. There were fundraising activities by fisheries associations, as in the case of the blue swimming crab association where a fundraising campaign helped raise enough to provide funds for 2 weeks (IDR250,000 [approximately USD15]) for each family of mini-plantpickers (mostly women) and fishers (a total of about 24,000 families). A private group set up a crowd-funding site to help raise funds for fishers. The government helped fishers in marketing through 'Warung Kemensos' (social stalls/shops) and online marketing, distribution of MSMEs products in hospitals, and inclusion of fish in the food packages under the local central government aid programs (e.g., "Program Keluarga Harapan", "Bantuan Pangan Non Tunai").

\section{Emerging lessons}

The pandemic highlighted the vulnerability of the fishers to disruptions in their livelihood and their high dependence on fishing. The inclusion of fish as a staple food for Indonesians provided the fishers with a ready market for their fish. The cash assistance that fishing households received was able to help households meet basic food needs. However, this assistance did not cover all fishers affected by the pandemic.

The pandemic also highlighted the importance of cold storage facilities. The cold storage facilities of both the government and private sectors were utilised at their maximum capacity to store fish to sell at a better price or to store fish for distribution to cities and provinces. Digital marketing platforms for fish products emerged. Many sellers in coastal communities creatively utilised this platform to channel their products. Some initiated their own simple reselling of fish products utilising online messaging applications in their areas to meet the demand of households.

\section{Malaysia}

\section{Disruption to small-scale fisheries}

In Malaysia, the COVID-19 pandemic and its associated government preventive measure of the Movement Control Order (MCO) beginning 18 March 2020 onwards disrupted supply chains and limited the movement of people. The shorter fishing hours and difficulty in selling fish in the market reduced the income and welfare of fishers. For example, about 13,000 fishers in Sarawak experienced drastic demand reduction as customers feared going out when ordered to stay at home (Abdullah, 2020). Moreover, the demand for fish from restaurants and hotels was significantly reduced by $30 \%$. According to the Malaysian Association of 
Hotels, the average occupancy rate of hotels in Malaysia dropped sharply from $60 \%$ in 2019 to $33 \%$ in January to August 2020 (Ganesan, 2020). The reduction of work hours and restrictions of movement was for both men and women. The decrease in catch may have also reduced the income of women workers involved in fish processing in the coastal areas due to disruptions in the supply chain.

\section{Coping strategies}

In Malaysia, the small-scale fishers are poor, and they depend on government subsidies to sustain their livelihoods. The average income of fishers was MYR700 (USD175) to 800 (USD200) per month before COVID-19, lower than the national minimum wage of MYR1,200 (USD300) per month. The small-scale fishers depend on the MYR250 (USD62) monthly income support from the government and diesel subsidy of MYRO.53 (USD0.13) per litre to travel to the sea to catch fish. During the MCO implementation, the small-scale fishers suffered income loss and relied on the Malaysian Fisheries Development Authorities (LKIM) and fisher associations to buy their catch.

\section{Relief and support received}

The Malaysian federal government announced a number of economic stimulus packages to assist vulnerable groups such as small-scale fishers affected by the MCO. Overall, the Malaysian Government has allocated MYR1 billion (USD0.25 billion) for the nation's food security fund under the second stimulus package. Specifically, it includes an allocation of MYR200,000 (USD50,000) special funds to fisher associations to assist them to develop shortterm agri-food projects that can produce food within 3 to 6 months and ensure the food supply is sufficient (Idris, 2020). In addition, MYR100 million (USD25 million) was allocated towards the development of food storage and distribution infrastructure. There are currently about 126,595 fishers in Malaysia (Department of Fisheries Malaysia, 2019).

In August 2020, the Ministry of Agriculture and Food Industry allocated MYR1.17 million (USDO.3 million) to implement the Economic Stimulus Package under the myFisheries Community (myKP) program to assist fishers in 13 areas nationwide. The stimulus package included fishing equipment, fish aggregating devices (fish shelter [unjam] or fish houses [tukun]), and cabins at the myKP Fisheries Transformation Centre (FTC)(Malay Mail, 2020). In September 2020, under the Prihatin Supplementary Initiative Package totalling MYR7 billion (USD1.73 billion), the government provided a one-off cash payment of MYR1000 (USD247) to households belonging to the bottom 40 income group (monthly earning less than MYR4000 [USD990]), where most fishing households belong. The Sarawak Government allocated MYR600,000 (USD148,404) to LKIM to buy the catch from the fishers to maintain the income of fishers (Ling, 2020). In the 2021 national budget, announced on 6 November 2020, the Malaysian Government allocated funds totalling MYR151 million (USD37 million) to raise the monthly living allowance of every fisher from MYR250 (USD62) to MYR300 (USD74) (Bernama News, 2020).

\section{Emerging lessons}

Fishers are suppliers of fish, a valuable protein source for the population. Adequate local fish supply helps stabilise the price of fish. Fishers, however, are highly vulnerable to disruptions such as those brought on by the COVID-19 pandemic. The small-scale fishers in Malaysia have hardly any savings, have little cash flow to sustain their livelihood in the event of a catastrophe, and do not have enough social protection.

Help for the fishing community is needed to enhance their resilience. This includes providing social infrastructure and safety nets (such as Employees Provident Fund or social security funds), and other assistance to prepare them for catastrophes similar to COVID-19. Moreover, fisher's cooperatives or associations need to be strengthened through capacity-building initiatives to make them more functional and organised. A more functional and organised fisher association can help the fishers market their fish products in the markets and increase their ability to deal with catastrophes such as the COVID-19 pandemic.

\section{Myanmar}

\section{Disruption to small-scale fisheries}

The health measures taken by the Government of Myanmar (GoM) to combat the COVID-19 pandemic were impositions of lockdown (i.e., 'stay at home'), curfews, and transport restrictions (air, road, river, and sea). The international and domestic airports were closed to all but relief flights, in addition, land borders were shut. These measures disrupted the movement of people and fisheries products as well. The main export markets for Myanmar's aquatic food are China and Thailand; hence the closure of the borders had a serious impact on exports during the first half of 2020 .

Small-scale fisheries, both inland and coastal, are of great importance to the people of Myanmar. Women account for about 50 percent of the workforce in the Myanmar fisheries sector when secondary elements such as processing and trading are included. Inshore fishing activities involve many women and children who participate in gleaning or trapping marine resources close to shore and using non-motorized dugout canoes (Tezzo et al., 2018). The annual inland fishery production amounts to 900,000 tons, while marine capture (coastal and offshore) amounts to 
1,150,000 tons (FAO, 2020a). Overall, the small-scale fisheries annual production is over 2 million tons and more when an unaccounted yet estimated 200,000 tons of unregistered 'hidden harvest' is added.

WorldFish carried out a telephone survey from March 2020 to August 2020 to show some of the direct effects of disruptions in the supply and consumption of food, including fish and other aquatic products (Belton et al., 2021). Results showed that inland small-scale fisheries fell dramatically from February, when $88 \%$ of fishers said that they were able to fish, to $12 \%$ in June, and then to $20 \%$ in July. These figures need to be taken in the context in that the peak inland fishing months correspond to the lowest water levels when fish are aggregated from December to February. In addition, the inland fisheries closed season is from May to July inclusive, however, many fishers and non-fishers fish (i.e., farmers, farm labourers, unemployed labour returning to villages) during closed seasons. The number of fishing days per month dropped from 20 in February to 4 in July. In April, 50 \% of fishers reported consuming their catch, although the quantities consumed were small at about $2 \mathrm{~kg}$.household ${ }^{-1}$. Twenty-one percent of fish traders were inoperative during the period from February to April when the lockdown closed wet markets and all restaurants, including hotels and tourist sites. By June, $47 \%$ of traders were not operating. For small-scale inland capture fisheries, the highest sales were reported during March to May, followed by a total collapse in July. Prices for fish declined gradually over the survey period as consumers either had no access to markets or producers stopped supplying fish due to the low demand.

Moreover, the monitoring by WorldFish and OIKOS within five fishing villages in the buffer zone of Lampi Island, Myanmar's only Marine National Park, demonstrated the precarious nature of artisanal fishers' livelihoods. Most of the 1,000+ fishers operating in the area fish for cuttlefish and squid marketed directly to Thai buyers who provide ice and food items to the fisher families. The price for fresh cuttlefish pre-COVID-19 was USD5.5 $\mathrm{kg}^{-1}$. Once the border closed and the trade stopped, fishers could only attain USD1.85 $\mathrm{kg}^{-1}$ on the local market. Furthermore, their access to food was limited.

\section{Relief and support}

The Government of Myanmar set up a COVID-19 Economic Relief Plan (Ministry of Planning and Finance, 2020), and by mid-November 2020, 1,600 applications were received from the Myanmar Fisheries Federation, a private sector coordinating body representing fisher and farmer members. Of these requests, 400 were approved to receive loans to help mitigate the negative impacts of COVID-19. It is expected that further loans will be authorised before the end of 2020. Aside from loans, fisher communities received health information on COVID-19 prevention. In some cases, there were also soap and masks provided.

\section{Emerging lessons}

COVID-19 is having a negative impact on small-scale fisheries in Myanmar due to reduced movement restricting the flow of products to the traditional wholesale centres and consumers' access to wet markets. Prices of products dropped while the transport cost increased due to control measures and the increased time taken to complete journeys (often without a return trip cargo). Closed borders reduced the export market options, especially to China and Thailand. Unemployed labour returning to villages from Myanmar and abroad has increased fishing pressure by those without incomes seeking access to food. By mid-November 2020 the positivity rate for COVID-19 had started to drop (Ministry of Health and Sports, 2020) although travel restrictions are likely to remain in place until a vaccination system is in place, hence it is assumed that the SSF sub-sector will continue to experience setbacks. A further shock to the fisheries sector has been the recent political turmoil after 1 February 2021. The impact will not be known until mid-2021.

\section{Philippines}

\section{Disruption to small-scale fisheries}

The national government of the Philippines placed a number of provinces and cities under Enhanced Community Quarantine (ECQ) in mid-March 2020 in response to the COVID-19 pandemic. The ECO meant "stay at home" as mobility and transportation (air, water, land) were restricted. Despite the pandemic and associated measures, the country's total fisheries production during the first three-quarters of 2020 was higher by $1.24 \%$ compared to the first threequarters of $2019(3,181,377.15$ MT vs. 3,142,428.90 MT) (Philippine Statistics Authority, 2020). By sector, however, the municipal (small-scale) fisheries sector recorded lower production by $1.83 \%(843,817.01$ MT vs. $828,393.10 \mathrm{MT})$, which is in contrast with higher commercial fisheries production by $6.71 \%(730,066.69$ MT vs. $779,039.27$ MT) and aquaculture production by $0.34 \%(1,568,545.20$ MT vs. $1,573,944.78$ MT). The municipal fisheries production decline was highest during the second quarter of $2020(7.02 \%)$, coinciding with the early months of the strictest level of the community quarantine. It recovered during the third quarter when selected sectors of the economy were partially opened, but the recovery was not enough to cover the dip in the second quarter.

Considered the poorest (Philippine Statistics Authority, 2017), the municipal (small-scale) fishers lives were difficult during the pandemic. Stories of fishers (men and women) publicly shared (e.g., Novio, 2020; Mirasol, 2020; Cabico, 2020a) on social media 
platforms of various fisheries groups described the hardship caused by limited fishing and marketing activities and the need to fend for themselves given the lack of a meaningful social assistance package, especially in the early months of the community quarantine. The women in the fishing households who usually carry out the fish marketing were greatly affected (i.e., had to stop or had to walk to reach buyers) by the mobility and transportation restrictions. Moreover, similar to experiences with past disasters, the burden of food insecurity was predominantly placed on women during the pandemic.

Although the government issued a directive that fishing was exempted from restrictions, there was confusion in the early months of implementation. Small fishers were apprehended by maritime authorities for allegedly violating quarantine protocols (Mirasol, 2020; Pedrajas, 2020; Miraflor, 2020; Novio, 2020), and local government units (LGUs) disobeyed the national order allowing fishing and the free-flow of fish amid the COVID-19 pandemic (Ocampo, 2020; Biong, 2020a). The lack of transportation (especially from March to May) reduced fish marketing. The closure of the ice plants and the hours of queues at checkpoints resulted in fish spoilage (Mirasol, 2020). The fishers of high-valued species (e.g., crabs, oysters, lobsters, groupers) were affected by the closure of restaurants, cancellation of events, and temporary closure of wet markets and fish ports (Gubalani, 2020; Letigio, 2020; Marzan, 2020).

The pandemic highlighted the power dynamics between the small-scale fishers and the commercial fishers who had the means to continue and sustain their fishing and trading operations. The commercial fishers continued to encroach in the municipal fishing grounds reserved for the small-scale fishers and their presence increased during the pandemic (Cabico, 2020b; Novio, 2020).

\section{Coping strategies}

The fishers were recognised as "food security frontliners" (Cator, 2020; DA-BFAR, 2020) and to play a crucial part in the fight against COVID-19. The government allowed fishing activities to continue and the free flow of fishery products by issuing food passes and local transport permits to fishers. But most small-scale fishers continued to fish for food, resorted to direct selling to neighbours for a lower price, and relied on government support. With strict transportation restrictions during the early months of the community quarantine, selling fish, particularly by women meant selling nearby or walking farther distance for a longer time to reach particular buyers. Other women have organised themselves and started a market for their catch or started to sew and sell cloth masks.

\section{Relief and support received}

Republic Act No. 11469, passed in March 2020, details the initial response measures of the government to the COVID-19 pandemic. Among other provisions, the fiscal package targeting the vulnerable groups included a cash aid program for senior citizens and low-income households, social protection measures for displaced workers, loans and credit guarantees for small businesses, and agricultural sector support. Specifically, the support by the national government to small-scale fishers during the pandemic included: i) Ioan provision of PHP25,000 (USD521) each at zero interest rate under the PHP2.8 billion (USD58.33 million) Survival and Recovery (SURE) Aid Program (Mirasol, 2020); ii) subsidy in the form of PHP2,000 (USD41), a voucher for food items and a cash voucher worth PHP3,000 (USD62) under the Cash and Food Subsidy for Marginal Farmers and Fisherfolk Program; iii) livelihood support programs through provision of fishing gears and boats under the Special Area for Agricultural Development Program, the PHP21.9 million (USD456,250) worth of production inputs (that includes fingerlings and seaweed dispersal, production-related technology demonstration projects) under the Ahon Lahat, Pagkaing Sapat Laban sa Covid program (Tecson, 2020); and, iv) provision of marine floating fish cages project to fishers associations under the Targeted Actions to Reduce Poverty and Generate Economic Transformation program.

Meanwhile, the local government units (LGUs) played a greater role in supporting the small-scale fishers during the early months of the community quarantine by providing them with food packs and buying fish for relief operations (DA-BFAR Memorandum dated 23 April 2020; Biong, 2020b). In July 2020, the DA Communications Group (2020) reported 442 LGUs procured directly from farmers and fishers for their food packs, generating PHP2.6 billion (USD54.2 million) in sales.

\section{Emerging lessons}

While the pandemic and the accompanying policy of community quarantine highlighted the fishers' role in maintaining food supply amid crisis, it exposed their poverty, vulnerability, and marginalisation. They were unprepared and lacked any viable way to cushion the impact of disruptions on their livelihood. Most of the support (loan, cash, food packs, and fishing inputs) came in the middle-to-end of the year, signifying the lack of systematic program support for them, which was long overdue by the small-scale fisheries sector.

The pandemic also reminded of the importance of the fight against illegal fishing, the importance of shifting to value-addition or processing seafood products, and the importance of fisheries storage facilities. Direct fish marketing and home delivery services flourished. The direct procurement by LGUs from the fishers has 
created a sure market for the catch while ensuring food security.

\section{Thailand}

\section{Disruption to small-scale fisheries}

In early 2020, the COVID-19 pandemic made adverse impacts on the small-scale fishery of Thailand, despite immediate enforcement of restrictive measures and a comparatively low number of COVID19 cases. When the government enforced a nationwide lockdown and curfew measures starting in early April 2020, travel across provinces, and country borders were restricted, and domestic and international flights were suspended. These government control measures, although necessary, affected the economy of the country, especially the fisheries and service sectors.

The fisheries sector in Thailand includes the artisanal (small-scale) fishery and the commercial fishery (DOF, 2015). In 2020, there were about 57,000 registered fishing vessels in Thailand (MD, 2020), of which around 47,000 were small scale fishing vessels (DOF, 2020a). The small-scale fisheries contribute around $10 \%$ of the total marine capture fishery production (DOF and CCCIF, 2017).

The lockdown measures caused differential impacts on fishing activities in the country. Small-scale fishers stopped fishing or decreased fishing effort due to low fish demand and price; other small-scale fishers continued fishing within their locality when the fishing time was not within the curfew hours (or secured a permit document when the fishing time was within the curfew hours). But there was difficulty maintaining the quality of fish and fishery products delivered outside the provincial areas due to travel restrictions (Chanrachkij et al., 2020).

Most activities were discontinued in factories for fish processing because of a shortage of raw materials since many fishers stopped fishing (Chanrachkij et al., 2020; Kaewnuratchadasorn et al., 2020). It was also difficult to sell the processed products due to limited transportation services and reduced demand from consumers (Chanrachkij et al., 2020).

With travel restrictions and a limited period of market operations, traders could not deliver the fish and fishery products to major fish markets. The suspension of most tourism activities due to the pandemic resulted in a significant decrease in the demand for fish and fishery products from this sector, including hotels and restaurants. Consumers' access to fish and fishery products was limited due to restriction measures in local markets (Chanrachkij et al., 2020). The health protocols as the government's main policy, such as stay-at-home and work from home, were also considered as one of the reasons for the limited access of consumers.

\section{Coping mechanisms}

Small-scale fishers extended their market channels and value-added to fish and fishery products (Chanrachkij et al., 2020). Many fishers turned to ecommerce or online selling of fish and fishery products. This became a family coping strategy in which young family members, who were more adept in information technology, actively facilitated online selling. Fishers also resorted to direct selling of their catch to customers in their community and intensified fish processing (e.g., sun drying); thus, they still earned some income when the fish price was low.

\section{Relief and support received}

The relief measures available for small-scale fishers (for both women and men) were financial assistance, food and daily subsistence goods, and low-interest bank loans. The national government provided financial assistance (THB5,000 or around USD160 per person for each month from April to June 2020) to registered farmers in the agricultural sector and temporary workers or freelancers outside the agricultural sector (OPM and UN, 2020). DOF (2020b) reported that more than 200,000 fishers in smallscale and commercial fisheries received financial assistance from the national government. The local governments also provided food and daily subsistence goods (Chanrachkij et al., 2020). The Department of Fisheries (DOF) and the government banks (i.e., the Bank for Agriculture and Agricultural Cooperatives and the Government Savings Bank) partnered to provide low-interest bank loans to fishers under the programs "Ouick Loan Support for Persons Affected by COVID-19" (maximum of THB10,000 or around USD320) (Bangkokbiznews, 2020) and "Loan for Enhancement Liquidity for Fishery Entrepreneurs Project" (maximum of THB5 million or around USD0.16 million)(DOF, 2020c).

\section{Emerging lessons}

During the COVID-19 pandemic, e-commerce became a common fish marketing strategy supporting smallscale fishers and improving consumers' access to fish and fishery products. However, the skills in online marketing and fish handling techniques of small-scale fishers, especially women and young people, still need to be enhanced to maximise the potential of this marketing strategy while ensuring the safety and quality of fish and fishery products, respectively (Chanrachkij et al., 2020; Kaewnuratchadasorn et al., 2020). Moreover, to offset the decreased demand for seafood from the tourism sector, the promotion of fishery products to local consumers at affordable prices should be strengthened (Kaewnuratchadasorn et al., 2020). Lastly, the establishment of small-scale fishers' groups could foster coordination among fishers, government, non-government organisations, and other relevant stakeholders in developing 
resilience strategies to mitigate the impacts of pandemics and other disasters in the future, such as the provision of micro-finance schemes to cushion the economic effects of similar disruptions in the future (Chanrachkij et al., 2020).

\section{Vietnam}

\section{Disruption to small-scale fisheries}

Vietnam is lauded as one of the countries with successful measures against COVID-19 with their strict enforcement of "tracing and chasing" efforts since early 2020. Although the pandemic and the associated preventive measure of quarantine affected the economy as a whole, it did not significantly disrupt the SSF during the first wave (February to May 2020), except in few areas where lockdown was imposed. However, the disruptions experienced in coastal provinces such as Hai Phong, Quang Ninh, Quang Nam, and Da Nang or even Binh Thuan and Ninh Thuan provinces, did not last long.

During the second wave of COVID-19 (from June to August), there were also no major adverse impacts as the local authorities were already experienced and well-prepared to mitigate the problem. The form of disruptions in the SSF included i) the reduction in fishing efforts due to difficulty in transporting their catch to the market; and ii) the low demand for fish due to the closure or limited access to domestic markets (including local and central markets); and, the drastic reduction in tourism activities.

Among women in fisheries, their activities of fish selling, processing, or buying inputs for fishing trips continued. The difference was on the frequency of holding these activities when fishing activities were limited or reduced by COVID-19, especially during the first wave. Women organisation such as the women union and other similar social groups (e.g., youth union, veteran association) significantly contributed to enhancing awareness on COVID-19 and how to prevent it.

\section{Relief and support measures}

Although the impacts of COVID-19 are not significant to the SSF of Vietnam, the Government of Vietnam still provided relief measures such as financial assistance, food subsidy, and low-interest bank loans. Everyone impacted by COVID-19 was provided assistance, especially the poor. The significant policies of support for the people to overcome the adverse impacts of COVID-19 were: i) Financial support package of VND61.58 trillion (USD2.67 billion) for the poor and enterprises affected by the COVID-19, of which more than VND52 trillion (USD2.25 billion)to support six eligible groups (including the poor, the people with meritorious services, people who lost their job, and others), VND9.5 trillion (USD411.64 million) to support enterprises; ii) Directive No. 11/CT-
TTg dated 4/3/2020 relating to urgent tasks and measures to reduce difficulties for production and business, ensuring social security to cope with COVID-19; iii) Official Letter No. 897 / TCT-QLN dated $3 / 3 / 2020$ on the extension of tax payment deadline and exemption of late payment interest; iv) Decree 41/2020/ND-CP dated 8 April 2020 of Government extending the time limit for payment of value-added tax, corporate income tax, personal income tax, and land rental; and, v) Resolution No. 42 of Government on support for social security to ensure a basic standard of living for the people, especially the poor and the unemployed. There were other policies implemented to ensure domestic food supply and food reserves and to promote agricultural production to maintain stability countrywide.

\section{Emerging lessons}

The cooperation and collaborative efforts of the government, all economic sectors, and the people are important against disruptions like the COVID-19 pandemic and its associated preventive measures. The pandemic presented an opportunity to use new strategies that work and can be applied in the future. This includes online commerce, safe (distancing) at work, safe transportation and delivery of food products. The pandemic also showed that the implementation of financial and investment support could help the people of Vietnam rise above the adverse impacts of the pandemic. However, other helpful strategies need to be explored, such as safe access to the food chain, safe food production management, and safe linkage between enterprises and cooperatives.

\section{Discussion}

Small-scale fisheries significantly contribute to the socio-economic well-being of coastal communities in Southeast Asia as providers of food, livelihood, and income, particularly to the poor, vulnerable, and marginal sector (Pomeroy, 2012; Teh and Pauly, 2018). Fisher households are prone to various crises and shocks that put a lot of stress on their already vulnerable condition, making them less economically resilient. Given the few assets of fishing dependent households, their ability to cushion the negative impact of crises and shocks is limited. Women, who work primarily on fish post-harvest activities, have been significantly impacted. The COVID-19 pandemic has delivered another serious threat to the livelihoods of these coastal households and communities.

The pandemic and the accompanying policies (in various names, but all meant as "stay at home") in the six countries demonstrated the far-reaching impacts on the fisheries and on the small-scale fishers and their livelihood. It has also highlighted the importance of the fisheries sector, the problems that have long existed and presented an opportunity to reshape it and learn lessons. It took a pandemic to highlight the 
role of the fisheries and the small-scale fishers. For example, in the Philippines, it emphasised the fishers' role in maintaining food supply amid crisis. In Myanmar, the unemployed labour returning to villages resulted in increased fishing pressure by those without incomes seeking access to food.

The effects of COVID-19 varied at different times and in different ways across the SSF in the six countries, reflecting the differences in their economic and social situation. The transportation and mobility restrictions caused fish trading to decline, if not halt, especially for high-value marine fish species sold at hotels and restaurants. Fish sales were redirected to local markets, and the use of e-commerce increased (Table 3). The effects are similar to that in many other parts of the world of the impacts of COVID-19 on the fisheries systems, in general (FAO, 2021; Love et al., 2020; Northrop et al., 2020); and, on the SSF (Bennett et al., 2020; Kaewnuratchadasorn et al., 2020; Chanrachkij et al., 2020; Campbell et al., 2020).

The pandemic has exposed the poverty, vulnerability, and marginalisation of small-scale fishers. They were unprepared and lacked viable ways to cushion the impact of fishing and market closures on their households. The pandemic has further exposed the political and economic marginalisation by many governments to the small-scale fisheries sector. The small-scale fishers had to fend for themselves in the early months of the pandemic, while most government support to the fishers came in the middle-to-end of the year, signifying the lack of systematic program planning and action to support the small-scale fisheries sector. Indonesia, Malaysia, the Philippines, Thailand, and Vietnam all supplied financial help and food subsidies designed as shortterm coping strategies to address immediate challenges brought about by the pandemic. The financial help provided to fishing households was critically important to purchase necessities. Malaysia and the Philippines provided support for fishing gear and improved post-harvest infrastructure. Myanmar, the Philippines, Thailand, and Vietnam provided lowinterest loans to fishers. Indonesia and Malaysia strengthened their fish marketing systems.

The pandemic also showed fishers making positive changes to their livelihoods. Fishers in Indonesia, the Philippines, Thailand, and Vietnam made adaptive responses such as direct fish marketing, online marketing, and home delivery services. Also, direct procurement by the local government in Malaysia and the Philippines from the fishers created a sure market for their catch and at the same time ensures food security. There is a need to learn from the pandemic to be able to identify new and better approaches that will consider the impact of similar threats or

Table 3. Summary matrix of the lessons learned from COVID-19 in six Southeast Asian countries.

\begin{tabular}{|c|c|c|c|c|c|}
\hline Indonesia & Malaysia & Myanmar & Philippines & Thailand & Vietnam \\
\hline $\begin{array}{l}\text { - Fishers are } \\
\text { vulnerable to } \\
\text { disruptions } \\
\text { - Fish in relief } \\
\text { packages } \\
\text { create sure } \\
\text { and direct } \\
\text { market for } \\
\text { catch } \\
\text { - Importance } \\
\text { of cold } \\
\text { storage } \\
\text { during glut } \\
\text { - Online } \\
\text { marketing } \\
\text { works for } \\
\text { fish }\end{array}$ & $\begin{array}{l}\text { - Fishers are } \\
\text { vulnerable to } \\
\text { disruptions } \\
\text { - Need for social } \\
\text { infrastructure } \\
\text { and safety nets } \\
\text { - Need to } \\
\text { strengthen } \\
\text { fisheries } \\
\text { cooperatives }\end{array}$ & $\begin{array}{l}\text { - Fishers are } \\
\text { vulnerable to } \\
\text { disruptions } \\
\text { - Negative impact } \\
\text { on the small } \\
\text { scale fishers }\end{array}$ & $\begin{array}{l}\text { - Fishers are } \\
\text { vulnerable to } \\
\text { - Fisruptions } \\
\text { food supply amid } \\
\text { crisis } \\
\text { - Need for social } \\
\text { infrastructure } \\
\text { and safety nets } \\
\text { - Direct marketing } \\
\text { and online } \\
\text { marketing work } \\
\text { for fish } \\
\text { - Importance of } \\
\text { cold storage } \\
\text { during glut }\end{array}$ & $\begin{array}{l}\text { - Fishers are } \\
\text { vulnerable to } \\
\text { - Onlisruptions } \\
\text { - Direct marketing } \\
\text { - Fish handling } \\
\text { techniques } \\
\text { - Promotion of fish } \\
\text { to local } \\
\text { consumers } \\
\text { - Establishment of } \\
\text { fishers groups to } \\
\text { develop } \\
\text { resilience } \\
\text { strategies }\end{array}$ & $\begin{array}{l}\text { - Online } \\
\text { marketing } \\
\text { - Financial help } \\
\text { matters }\end{array}$ \\
\hline
\end{tabular}

disruptions on livelihood in the future. These adaptive responses can be carried forward, learned from, and further enhanced to address future shocks.

Emergency relief is usually delivered to an area due to a natural disaster, such as a typhoon, flood, or drought. While there was no physical damage resulting from the COVID-19 pandemic, the impacts may be more damaging as whole national, and international economies and societies have been affected. The economic and social disruptions have reverberated from individual fishing households through global seafood value chains. The COVID-19 pandemic has highlighted the need to think more broadly about planning how to respond to disasters. 
There is a need for long-term adaptive measures that can contribute to building specific and generalised household resilience to multiple shocks and stressors. In most cases, stressed fishing households with limited resources often resort to more extraction of the limited asset available to them, the fishery, and their natural capital. Fishers are forced by economic pressure to engage in unsustainable fishing practices in order to cope with either short or long-term stress i.e., education of children, health emergencies, etc.

The pandemic has emphasised the urgency for household resilience, a key concept for addressing the vulnerability of small-scale fishing households. A resilient fishing household should be able to evolve in response to changing stresses while maintaining its functionality even as capital (natural, financial, human, physical, social, and institutional) is restrained. There is a need for well-targeted actions to reduce inequalities by taking into account the heterogeneity in livelihood trajectories and unequal social vulnerability; to refocus and reallocate funds, specifically, programs for protecting and preventing the impact of COVID-19 for small-scale fishers, including the preparation of social safety net schemes (Tschakert and Hipsey, 2021).

Several approaches are recommended to improve fishing household resilience, and especially the integration of women (Stacey et al., 2019). The first is to strengthen the fishing households' social network of friends, relatives, and neighbours - social capital. This can serve as both a social safety net and a bridge toward the transition to financial inclusion. The second is livelihood diversification (Pomeroy et al., 2017) to reduce dependency on the fishery and provide for additional sources of income and food. Although the existence of livelihood alternatives beyond the fishery could be a crucial factor in building household resilience, the creation of such options is difficult to accomplish in practice. Income diversification can only sustain natural resources and improve human well-being if it truly transforms livelihoods by connecting local users in new ways to economies and societies (Hanh and Bonstra, 2018). In the case of COVID-19 pandemic, some fishing households use it as an opportunity to diversify their livelihoods through alternative fish marketing strategies. Fishers' wives assist in securing alternative livelihoods such as selling food and becoming housemaids.

The third is financial inclusion through savings, credit, digital payment products, and insurance that has all been found to increase resilience and cut risk (Pomeroy et al., 2020) to address the lack of financial cushion to mitigate disaster impacts. The fourth is value chain upgrading through post-harvest fish handling and processing methods (including market infrastructure improvements) to stabilise and increase local fishers' income through cost efficiencies and quality improvements that allow fishers to retain more value (Lomboy et al., 2019). Market "pull" investments may help the fishers to meet market requirements and link them to markets through fresh seafood sourcing and responsibly caught products. The fifth is the provision of access, especially for women, to social protection measures such as government health insurance and social security.

\section{Conclusion}

This paper describes the disruptions to and responses by the small-scale fisheries to the COVID19 pandemic and the accompanying lessons learned in six countries in Southeast Asia. Fishing households are some of the most economically vulnerable people in the region, with one of the highest poverty rates. Fishing households are stressed by factors within fishery systems, as well as by ecological and social impacts outside their influence such as climate change, chronic pollution, resource degradation, fluctuating prices of commodities, conflicts over resource use that increase vulnerability and changes in management strategies that can asymmetrically affect different communities. COVID-19 has only added to this list of stressors.

Given the few assets of a fisher household, their ability to cushion the negative impact of crises and shocks is limited. While short-term responses of providing food and financial assistance have been helpful, long-term support to address not only pandemics such as COVID-19 but also other stressors will require developing more resilient fishing households. It requires addressing fundamental social, economic, and environmental reforms that affect coastal communities and livelihoods. Achieving progress in this direction means those providing assistance must engage coastal communities in a dialogue about the future they envision, the steps needed to get there, and the lessons learned along the way. In the recovery efforts, if the small-scale fishers are not left behind, then it will be a "best normal", otherwise, it will be a "worst normal."

A limitation of the study is that due to travel restrictions in each country resulting from COVID-19, it was impossible to conduct primary surveys of households to fully understand impacts and responses. When it is safe to travel again, it is recommended that surveys be conducted of fishing households to gain more knowledge about the impact and responses to COVID-19.

\section{References}

Abdullah, M. 2020. Fishermen bemoan drop in sale. The Borneo Post. https://www.theborneopost.com/2020/03/30/fishermen-bemoandrop-in-sale/(Accessed 16 December 2020).

Ayunda, N., Sapota, M.R., Pawelec, A. 2018. The impact of small-scale fisheries activities toward fisheries sustainability in Indonesia. In: Interdisciplinary approaches for sustainable development goals. 
GeoPlanet: Earth and planetary sciences, Zielinski, T., Sagan, I., Surosz, W. (Eds). Springer, Cham, pp. 147-167. https://doi.org/10.1007/978-3-319-71788-3_11

Bangkokbiznews. 2020. https://www.bangkokbiznews.com/news /detail/910210 (Accessed 29 December 2020).

Belton, B., Rosen, L., Middleton L., Gazali, S., Mamun, A.A., Shieh, J., Noronha,H.S., Dhar,G., llyas, M., Price, C., Nasr-Allah, A.M., Elsira, I., Baliarsingh, B.K., Padiyar, A., Rajendran, S., Mohan, A.B., Babu, R. Akester, M.J., Phyo, E.E., Khin, M.S., Olaniyi, A., Siriwardena, S.N., Bostock, J., Little, D.C., Phillips, M.J., Thilsted, S.H. 2021. COVID-19 impacts and adaptations in Asia and Africa's aquatic food value chains. Penang, Malaysia: CGIAR Research Program on Fish AgriFood Systems. Working Paper: FISH-2021-02, 31 pp. https://digitalarchive.worldfishcenter.org/bitstream/handle/20.500 .12348/4497/fa616a1fef7b31247610de33f720f9fe.pdf

Bennett, N.J., Finkbeiner, E.M., Ban, N.C., Belhabib, D., Jupiter, S.D., Kittinger, J.N., Mangubhai, S., Scholtens, J., Gill, D., Christie, P. 2020. The COVID-19 pandemic, small-scale fisheries and coastal fishing communities. Coastal Management 48:336-347. https://doi.org/10.1080/08920753.2020.1766937

Bernama News. 2020. Budget 2021: RM1.7 billion subsidies to assist farmers, fishermen. Bernama News Online. https://bernama.com len/business/news_penjana.php?id=1897981 (Accessed 16 December 2020).

Biong, I. 2020a. DA, DILG: 'Unhampered movement' of agri-fishery products through checkpoints. Inquirer. https://newsinfo.inquirer .net/1251616/da-dilg-promises-unhampered-movement-of-agrifishery-products-through-checkpoints (Accessed 15 December 2020).

Biong, I. 2020b. DA urges LGUs to buy produce from local farmers, fisherfolk. Inquirer. https://newsinfo.inquirer.net/1267463/daurges-lgu-chiefs-to-buy-produce-from-local-farmers-fisherfolk (Accessed 15 December 2020).

Cabico, G.K. 2020b. Oceana: Commercial fishing boats seen in municipal waters as gov't preoccupied with COVID-19 fight. Philstar. https://www.philstar.com/nation/2020/04/02/2005101/oceanacommercial-fishing-boats-seen-municipal-waters-govtpreoccupied-covid-19-fight (Accessed 17 December 2020).

Cabico, G.K. 2020a. Recovery plan for fisheries sector focuses on food security, aquaculture. Philstar. https://www.philstar.com/nation /2020/08/27/2038374/recovery-plan-fisheries-sector-focusesfood-security-aquaculture (Accessed 17 December 2020).

Campbell, S., Jakub, R., Valdivia, A., Setiawan, H., Setiawan, A., Cox, C., Kiyo, A., Darman, Djafar, L., dela Rosa, E., Suherfian, W., Yuliani, A. Kushardanto, H., Muawanah, U., Rukma, A., Alimi, T. Box, S. 2020. Impact of COVID-19 on small-scale fisheries of Southeast Sulawesi, Indonesia. Research Square. https://doi.org/10.21203/rs.3.rs$\underline{39895 / v 1}$

Cator, C. 2020. DA: Agriculture and fisheries workers are frontliners in COVID-19 fight. CNN Philippines. https://www.cnnphilippines.com /news/2020/4/11/da-agriculture-and-fisheries-players-workersfrontliners-coronavirus.html (Accessed 17 December 2020).

Chanrachkij, I., Laongmanee, P., Lanmeen, J., Suasi, T., Sornkliang, J., Tiaye, R., Yasook, N., Putsa, S., Chumchuen, S.V. 2020. Severity of the impacts of COVID-19 pandemic on small-scale fisheries of Thailand: a preliminary assessment. Fish for the People 18:43-47.

Clavelle, T. 2020. Global fisheries during COVID-19. In: Global Fishing Watch. https://globalfishingwatch.org/data-blog/global-fisheriesduring-covid-19/(Accessed 4 December 2020).

CSIS. 2020. Southeast Asia Covid-19 Tracker. https://www.csis.org /programs/southeast-asia-program/southeast-asia-covid-19tracker-0 (Accessed 4 December 2020).
DA Communications Group. 2020. DA: Agri-fishery sector performs well, amid COVID-19 pandemic. https://www.da.gov.ph/da-agrifishery-sector-performs-well-amid-covid-19-pandemic/ (Accessed 15 December 2020).

DA-BFAR Memorandum. 2020. Submission of list of LGUs purchasing agricultural and fishery food commodities directly from farmers/fishermen cooperatives and/or associations. https://www.da.gov.ph/covid-19-food-resiliency-task-forceissuances/(Accessed 29 November 2020).

DA-BFAR. 2020. Press release: DA-BFAR sustains programs, services despite community lockdowns due to COVID-19. https://www.bfar .da.gov.ph/BFARnews?id=360 (Accessed 29 November 2020).

Department of Fisheries Malaysia. 2019. 2019 Annual fisheries statistics of Malaysia. https://www.dof.gov.my/index.php/pages/view/4046 (Accessed 16 December 2020).

DOF, CCCIF. 2017. Marine fisheries management plan of Thailand: A national policy for marine fisheries management 2015-2019. Department of Fisheries, Bangkok. 116 pp.

DOF. 2015. http://www.ratchakitcha.soc.go.th/DATA/PDF/2558/A/108 11.PDF (Accessed 1 November 2020).

DOF. 2020a. https://elicense.fisheries.go.th (Accessed 28 December 2020).

DOF. 2020b. https://www4.fisheries.go.th/dof/news_local/1210/87106 (Accessed 24 December 2020).

DOF. 2020c. https://www4.fisheries.go.th/local/index.php/main /view_activities/1386/80349 (Accessed 25 December 2020).

Drury O'Neill, E., Crona, B., Ferrer, A.G., Pomeroy, R. 2019. From typhoons to traders: the role of patron-client relations in mediating fishery responses to natural disasters. Environmental Research Letters 14:045015. https://doi.org/10.1088/1748-9326/ab0b57

FAO. 2020. The state of world fisheries and aquaculture http://www.fao.org/publications/sofia/2020/en/ (Accessed 15 November 2020).

FA0. 2020a. Summary of the impacts of the COVID-19pandemic on the fisheries and aquaculture sector: Addendum to the State of World Fisheries and Aquaculture 2020. FAO, Rome. 4 pp https://doi.org/10.4060/ca9349en (Accessed 15 November 2020).

FAO. 2020b. The impact of COVID-19 on fisheries and aquaculture - a global assessment from the perspective of regional fishery bodies. Initial assessment, No. 1. FAO, Rome. 35 pp.

FAO. 2020c. How is COVID-19 affecting the fisheries and aquaculture food systems. Rome. 5 pp. https://doi.org/10.4060/ca8637en (Accessed 15 November 2020).

FAO. 2021. The impact of COVID-19 on fisheries and aquaculture food systems, possible responses: Information paper, November 2020. FAO, Rome. https://doi.org/10.4060/cb2537en

Ganesan, V. 2020. Hotel's hopes for narrower losses fade as Covid-19 cases surge. The Edge Malaysia News Online. https://www.theedgemarkets.com/article/hotels-hopes-narrowerlosses-fade-covid19-cases-surge (Accessed 29 November 2020).

Gubalani, R. 2020. GenSanfishport to shut down for 4 days amid rising Covid cases. https://www.pna.gov.ph/articles/1113900 (Accessed 15 December 2020).

Halim, A., Wiryawan, B., Loneragan, N.R., Hordyk, A., Sondita, M.F.A., White, A.T., Koeshendrajana, S., Ruchimat, T., Pomeroy, R.S., Yuni, C., 2019. Developing a functional definition of small-scale fisheries in support of marine capture fisheries management in Indonesia. Marine Pollution 100:238-248. https://doi.org/10.1016 lj.marpol.2018.11.044

Hanh, T.T.H., Boonstra, W.J. 2018. Can income diversification resolve social-ecological traps in small-scale fisheries and aquaculture in the global south? A case study of response diversity in the Tam 
Giang lagoon, central Vietnam. Ecology \& Society 3:16. https://doi.org/10.5751/ES-10207-230316

Idris, A.N. 2020. Covid-19 stimulus package: Government allocates RM1 billion for food security fund. The Edge Market News. https://www.theedgemarkets.com/article/covid19-stimuluspackage-govt-allocates-rm1b-food-security-fund) (Accessed 15 December 2020).

Islam, G., Noh, K., Sidique, S., Noh, A., Ali, A. 2014. Economic impacts of artificial reefs on small-scale fishers in Peninsular Malaysia. Human Ecology 42:989-998. https://doi.org/10.1007/s10745-014-9692-2

Kaewnuratchadasorn, P., Smithrithee, M., Sato, A., Wanchana, W., Tongdee, N., Sulit, V.T. 2020. Capturing the impacts of COVID-19 on the fisheries value chain of Southeast Asia. Fish for the People 18:28.

Kholis, M.N. 2020. Prediksi dampak Covid-19 terhadap pendapatan nelayan jaring insang di Kota Bengkulu. ALBACORE Jurnal Penelitian Perikanan Laut 4:001-011. https://journal.ipb.ac.id/index.php /pspalbacore/article/view/30920 (in Indonesian).

Knight, C.J., Burnham, T.L.U., Mansfield, E.J., Crowder, L.B., Micheli, F. 2020. COVID-19 reveals vulnerability of small-scale fisheries to global market systems. The Lancet Planetary Health 4:e219. https://doi.org/10.1016/S2542-5196(20)30128-5

Letigio, D.D. 2020. BFAR-7 facilitates fish donation to families affected by COVID-19 Beneficiaries from Cebu City, other towns and cities of Cebu. Cebu Daily News. https://cebudailynews.inquirer.net 1313498/bfar-7-donates-fish-to-families-affected-by-covid-19 (Accessed 16 December 2020).

Ling, S. 2020. Help for farmers. The Star News. https://www.thestar.com.my/metro/metro-news/2020/04/11/helpfor-farmers (Accessed 16 December 2020).

Lomboy, C., Belinario, M.F.M., Pomeroy, R., Pedrajas, J., Tirona, R., Box, S., Domondon, P. Balbido-Ramirez, K. 2019. Building household economic resilience to secure a future for near shore fishers in the Philippines. Marine Policy 99:334-342. https://doi.org/99. 10.1016/j.marpol.2018.11.013

Love, D., Allison, E., Asche, F., Belton, B., Cottrell, R., Froehlich, H., Gephart, J., Hicks, C., Little, D., Nussbaumer, E., Pinto da Silva, P., Poulain, F., Rubio, A., Stoll, J., Tlusty, M., Thorne-Lyman, A., Troell, M., Zhang, W. 2020. Emerging COVID-19 impacts, responses, and lessons for building resilience in the seafood system. Global Food Security 28:100494. https://doi.org/10.1016/j.gfs.2021.100494

Malay Mail. 2020. MyKP: Government allocated RM1.17 million to help fishermen. Malay Mail. https://www.malaymail.com/news/malaysia /2020/08/08/mykp-govt-allocated-rm1.17m-to-help-fishermen /1892224 (Accessed 16 December 2020).

Mardhia, D., Kautsari, N., Syaputra, L.I., Ramdhani, W., Rasiardhi, C.O. 2020. Penerapan protokol kesehatan dan dampak Covid-19 terhadap harga komoditas perikanan dan aktivitas penangkapan. Indonesian Journal of Applied Science and Technology 1:80-87. https://journal.publication-center.com/index.php/ijast/article /view/112 (in Indonesian with English abstract).

Marschke, M., Vandergeest, P., Havice, E., Kadfak, A., Duker, P., Isopescu, I., MacDonnell, M. 2020. COVID-19, instability and migrant fish workers in Asia. Maritime Studies 20:87-99. https://doi.org/10.1007/s40152-020-00205-y

Marzan, J.B.A. 2020. Fish port closure continues. Daily Guardian. https://dailyguardian.com.ph/fish-port-closure-continues/ (Accessed 17 December2020).

MD. 2018. http://www.ratchakitcha.soc.go.th/DATA/PDF/2561/E/201 IT23.PDF (Accessed 13 February 2021).

MD. 2020. https://whitelist.md.go.th/ship (Accessed 28 December 2020).
MDPI. 2020. Penilaiancepat (Rapid Assessment) dampak Covid-19 terhadapnelayan tuna handline. Yayasan Masyarakat dan Perikanan Indonesia, Denpasar, Indonesia. http://mdpi.or.id/images/pdf_list /publications_reports/202005_Laporan\%20Rapid\%20Assessment \%20Dampak\%20Covid-19\%20terhadap\%20Nelayan\%20Tuna $\% 20 \mathrm{HL}-M D P I-F i n a l . p d f$ (in Indonesian).

Ministry of Health and Sports. 2020. Covid-19 situation reports. 2020 https://mohs.gov.mm/page/9575 (Accessed 16 December 2020).

Ministry of Planning and Finance, Myanmar. 2020. https://www.mopfi.gov.mm/sites/default/files/COVID19\%20Economic\%20Relief\%20Plan(CERP)-Eng_0.pdf (Accessed 15 March 2021).

Miraflor, M.B. 2020. Fishermen appeal for systematic gov't solution. https://business.mb.com.ph/2020/05/24/fishermen-appeal-forsystematic-govt-solution/(Accessed 17 December 2020).

Mirasol, P. 2020. Farmers and fisherfolk share Covid-19 stories from the field. https://www.bworldonline.com/sparkup-community-farmersand-fisherfolk-share-covid-19-stories-from-the-field/ (Accessed 17 December 2020).

Northrop, E., Konar, M., Frost, N., Hollaway, E. 2020. "A Sustainable and equitable blue recovery to the COVID-19 crisis". World Resources Institute, Washington DC. http://www.oceanpanel.org/bluerecover (Accessed 15 December 2020).

Novio, E. 2020.Webinar report: Farmers, fisherfolk lament limited aid, logistical challenges brought by COVID19. https://www greenpeace.org/philippines/story/9589/webinar-report-farmersfisherfolk-limited-aid-logistical-challenges-covid19/ (Accessed 17 December 2020).

Ocampo, K.R. 2020. Año threatens action vs LGUs blocking goods. Philippine Daily Inquirer. https://newsinfo.inquirer.net/1249185/anothreatens-action-vs-Igus-blocking-goods (Accessed 17 December 2020).

OPM, UN. 2020. Social impact assessment of COVID-19 in Thailand. Oxford Policy Management, Oxford. $176 \mathrm{pp}$.

Pedrajas, J.A. 2020. 6 fishermen arrested for going out to fish in Muntinlupa. Manila Bulletin. https://mb.com.ph/2020/03/21/6fishermen-arrested-for-going-out-to-fish-in-muntinlupa/ (Accessed 17 December 2020).

Philippine Statistics Authority. 2017. Farmers, fishermen and children consistently posted the highest poverty incidence. https://psa.gov.ph/content/farmers-fishermen-and-childrenconsistently-posted-highest-poverty-incidence-among-basic (Accessed 12 December 2020).

Philippine Statistics Authority. 2020. OpenStat: Agriculture, Forestry, Fisheries. $\quad$ https://openstat.psa.gov.ph/PXWeb/pxweb/en/DB /DB__2E_FS/?tablelist=true\&rxid=bdf9d8da-96f1-4100-ae0918cb3eaeb313t (Accessed 12December 2020).

Pomeroy, R. 2012. Managing overcapacity in small-scale fisheries in Southeast Asia. Marine Policy 36:520-527. https://doi.org/10.1016 li.marpol.2011.10.002

Pomeroy, R., Arango, C., Lomboy, C., Box, S. 2020. Financial inclusion to build economic resilience in small-scale fisheries. Marine Policy. 118:103982. https://doi.org/10.1016/j.marpol.2020.103982

Pomeroy, R., Thi Nguyen, K., Thong, H. 2009. Small-scale marine fisheries policy in Vietnam. Marine Policy 3:419-428. https://doi.org /10.1016/j.marpol.2008.10.001

Pomeroy, R., Ferrer, A.J., Pedrajas, J. 2017. An analysis of livelihood projects and programs for fishing communities in the Philippines. Marine Policy 81:250-255. https://doi.org/10.1016 lj.marpol.2017.04.008 
Rare Indonesia. 2020. COVID-19 \& small-scale fisheries. https://rare.org/?s=COVID-19+\%26+Small-Scale+Fisheries

+ Rare+Indonesia (Accessed 30 November 2020).

Samah, A. A., Shaffril, H.A.M., Hamzah, A., Samah, B.A. 2019. Factors affecting small-scale fishermen's adaptation toward the impacts of climate change: Reflections from Malaysian fishers. SAGE Open 2019:1-11. https://doi.org/10.1177/2158244019864204

Stacey, N., Gibson, E., Loneragan, N.R. Fitriana, R., Warren, C., Wiryawan, B., Adhuri, D. 2019. Enhancing coastal livelihoods in Indonesia: an evaluation of recent initiatives on gender, women and sustainable livelihoods in small-scale fisheries. Maritime Studies 18:359-371. https://doi.org/10.1007/s40152-019-00142-5

Tecson, Z. 2020. BFAR gives livelihood support to fisherfolks in Bataan. https://www.pna.gov.ph/articles/1112295 (Accessed 15 December 2020).

Teh, L.C.L., Pauly, D. 2018. Who brings in the fish? The relative contribution of small-scale and industrial fisheries to food security in Southeast Asia. Frontiers in Marine Science 5:44 https://doi.org /10.3389/fmars.2018.00044

Tezzo, X., Belton, B., Johnstone, G., Callow, M. 2018. Myanmar's fisheries in transition: Current status and opportunities for policy reform. Marine Policy 97:91-100. https://doi.org/10.1016 lj.marpol.2018.08.031

Tschakert, P., Hipsey, M.R. 2021. Moving up or going under? Differential livelihood trajectories in coastal communities in Vietnam. World Development 138:105219. https://doi.org/10.1016/j.worlddev.2020 .105219

United Nations. 2020. Policy brief: The impact of COVID-19 on SouthEast Asia. United Nations. 29 pp. https://www.unescap.org/sites /default/d8files/2020-07/SG-Policy-brief-COVID-19-and-SouthEast-Asia-30-July-2020.pdf 